\title{
Histomorphological Study of the Anti-Fertility Effect of Spondias Mombin L. In Adult Male Rats
}

\author{
Olaitan Ruth Asuquo ${ }^{*}$, Theresa Bassey Ekanem², Paul Bassey Udoh ${ }^{3}$, \\ Mokutima Amarachi Eluwa ${ }^{4}$ \\ ${ }^{1,2,4}$ Department of Human Anatomy, Faculty of Basic Medical Sciences, University of Calabar, Cross River \\ State \\ ${ }^{3}$ Department of Zoology and Environmental Biology, Faculty of Science, University of Calabar, Cross River \\ State.
}

\begin{abstract}
The effects of ethanol extract of Spondias mombin leaf on male rats' fertility were investigated. The extract was orally administered with 250 and $500 \mathrm{mg} / \mathrm{kg}$ doses for 8 weeks. There was significant decrease in testicular and epididymal weight in the treated animals compared to the control. Histomorphology of the testis showed distortion in the arrangement of seminiferous tubules, loose germinal epithelium, low number of germ cells and Sertoli cells. Tubular sizes of epididymis were reduced with vacuolation and decreased sperm. The serum level of testosterone was significantly decreased $(p<0.05)$ at $500 \mathrm{mg} / \mathrm{kg}$ compared to control. We conclude that Spondias mombin leaf extract can suppress the process of spermatogenesis which can lead to infertility in laboratory animals.
\end{abstract}

Keywords: Epididymis, Infertility, Reduction, Spermatogenesis, Spondias mombin, Testis.

\section{Introduction}

Medicinal plants are distributed worldwide, but they are most abundant in tropical countries [1]. It is estimated that about 25 per cent of all modern medicines are directly or indirectly derived from plants [2]. According Bodeker et al, [3], 65 to 80 per cent of the world's population, living in developing countries, depends mostly on plants for health care due to poverty and lack of modern medicine. Traditional medicines are now widely accepted due to its cultural acceptability, compatibility with the human body, effectiveness and less side effects [4]. In Africa, rural communities depend on medicinal plants as a source of primary health care due to the high cost and unavailability of synthetic drugs [5]. Contraception is important to health, development, and quality of life and has allowed couples to plan their families and safely space births. Several methods of contraception for family planning had been used over the years, however, due to the adverse effect associated with synthetic contraceptives, herbal plants have been investigated for their contraceptive potentials[6 -12]. Several plants and plant products are reported to impede various stages of testicular function in many animal species such as dogs, rats, humans and monkeys [13-17]. However, several more plants have been used by indigenous traditional medicines as a form of contraceptive including Spondias mombin. It is relied on for various herbal remedies for numerous conditions with almost every part of the tree being used; from its thick corky bark, to its leaves, fruits, and roots to even its flowers. The leaves are locally used for various digestive problems including stomachaches, diarrhea, dyspepsia, gastralgia, colic, and constipation. It has been reported as a medicinal plant with potentials that is valuable and a source of active drugs for treating diseases that has not been fully tapped [18].

Biological activities of the plant include; uterine stimulant actions [19-20]; smooth muscle relaxant actions [21]; uterine antispasmodic [22]; sedative and anticonvulsant actions, and anti-anxiety actions [23,24]; anti-inflammatory[25]. Raji et al [26] showed the antifertility action of aqueous Spondias mombin bark extract. However, leaves of Spondias mombin is used by traditional birth attendants in Southern Cross River as an infertility agent. The present study was designed to investigate the histological alterations of testicular and epididymal tissues through two doses of oral administration of Spondias mombin in male rats' reproductive system.

2.1 Plant material and extraction

\section{Materials and Methods}

Leaves of Spondias mombin were harvested from a community in Yakkur, Cross River. The leaves were washed to remove dirt and dried. An ethanolic extract was prepared using the cold extraction method [27]. The leaves were finely powdered and $500 \mathrm{~g}$ of this powder was soaked in $1 \mathrm{~L}$ of $99.9 \%$ ethanol for 48 hours. The contents were filtered and ethanol was evaporated under reduced pressure in a rotary vacuum evaporator. This filtrate was dried at room temperature and dried mass was stored at $4^{\circ} \mathrm{C}$. The yield of extract was $4.6 \%$ of the 
starting raw material. Two different doses of 250 and $500 \mathrm{mg} / \mathrm{kg} /$ body weight/day were prepared from the stock solution by dissolving $4 \mathrm{~g}$ of the extract in $1000 \mathrm{ml}$ of physiological saline.

\subsection{Animals}

Adult male rats of Wistar strain $(n=30)$, were used. They were housed in wooden cages with standard laboratory diet and water was given ad libitum. They were kept for two weeks to acclimatize and then weighed. The Institutional Animal Ethical Committee clearance was obtained before the commencement of study.

\subsection{Dosage}

The animals were randomly divided into three groups $(\mathrm{n}=10)$. Group A served as controls, and were given normal saline. Animals in group B and C received different doses of extract orally ( 250 and $500 \mathrm{mg} / \mathrm{kg}$ respectively) for 8 weeks. The body weight of the rats was recorded weekly throughout the treatment period and also at the end of the treatment.

\subsection{Termination of experiment}

At the end of treatment, the animals were sacrificed under chloroform anesthesia. Blood was drawn through cardiac puncture and was centrifuged; plasma was separated and stored at $-20^{\circ} \mathrm{C}$ for testosterone analysis. Serum testosterone concentration was measured by Enzyme immunoassay (EIA) kit (Microwell method of DIALAB). Testis and epididymis were dissected out, blotted free of blood and weighed. Vernier callipers were used to measure the length and width of testes and epididymis.

\subsection{Histopathology}

Testes and epididymis were fixed in Bouin's fluid and embedded in paraffin. Sections were cut at $5 \mu \mathrm{m}$ and stained with haematoxylin and eosin. Testis and epididymis were studied under light microscope, photomicrographs were taken.

\subsection{Statistical analysis}

Mean \pm SEM of data of control and Spondias mombin treated groups were determined. The data was analyzed and compared by one way ANOVA. Level of significance was considered at $\mathrm{P}<0.05$.

\section{Results}

The present study investigated the influence of ethanolic extract of $\mathrm{SpM}$ leaves on testes and epididymis of Wistar rats for 8 weeks. Significant $(p<0.05)$ decrease in the weight of testes and epididymis in treated rats were observed compared to control, and also a significant $(\mathrm{p}<0.05)$ difference within the treatment groups (Table 1). Serum testosterone level in rats treated with $250 \mathrm{mg} / \mathrm{kg}$ and $500 \mathrm{mg} / \mathrm{kg}$ of $\mathrm{SpM}$ were significantly $(\mathrm{p}<0.05)$ reduced compared to control, with the value of the high dose being most significantly lower than that of the low dose (Table 2).

Tunical thickness, Leydig cell diameter, seminiferous tubule diameter, epithelial height and Sertoli cell diameters were measured histometrically (Tables 3). Cross sections of control rat's testis revealed compactly arranged seminiferous tubules, with Sertoli cells found between spermatogenic cells. Irregularly shaped Leydig cells were also seen. The seminiferous tubules were observed to be undergoing spermatogenesis (Fig 1). Marked degenerative changes were observed in the testis of the experimental rats. Alterations were observed in the histological appearance of the seminiferous tubules, with damage to the basement membrane and scanty cytoplasm was observed in the treated rats that received $250 \mathrm{mg} / \mathrm{kg}$ extract (Fig 2). Treatment with $500 \mathrm{mg} / \mathrm{kg}$ extract resulted in necrotic changes in the seminiferous tubules, shrunken nuclei of germinal epithelium, and total arrest of spermatogenesis (Fig 3).

Decrease in tubular diameter of epididymis was recorded in the treatment groups compared to control. The decrease was significant $(\mathrm{P}<0.05)$ in the high dose. A non-significant $(\mathrm{P}>0.05)$ decrease in epithelial height was recorded in the treated rats' epididymis compared to control (Table 4). Cross section of control epididymis showed compactly packed tubules, lined with well defined pseudostratified epithelium (Fig 4). A dosedependent impairment of epididymis was caused by extract treatment compared to control. The epididymal tubules in the low dose group showed hypertrophy of lumen and reduction of viable sperm cells (Fig 5). Epididymis of $500 \mathrm{mg} / \mathrm{kg}$ ethanol extract showed thinning of epithelial lining and loss of spermatic elements (Fig 6). 
Histomorphological Study of the Anti-Fertility Effect of Spondias Mombin L. In Adult Male Rats

Table 1: Effect of Spondias mombin extract doses on the mean testicular and epididymal weight and size in control and treated rats.

\begin{tabular}{|c|c|c|c|c|c|}
\hline \multicolumn{3}{|c|}{ Testes } & \multicolumn{3}{|c|}{ Epididymis } \\
\hline Group & Total weight & Total length & Total width & Total weight & Total length \\
\hline Control & $26.54 \pm 2.48$ & $16.26 \pm 0.92$ & $8.68 \pm 0.32$ & $0.084 \pm 0.05$ & $42.64 \pm 3.28$ \\
\hline $250 \mathrm{mg} / \mathrm{kg}$ & $18.98 \pm 1.57^{\mathrm{a}} * *$ & $14.62 \pm 0.36^{\mathrm{a} * *}$ & $7.24 \pm 0.85^{\mathrm{a} *}$ & $0.062 \pm 0.07^{\mathrm{a}} *$ & $38.43 \pm 2.02^{\mathrm{a} * *}$ \\
\hline $500 \mathrm{mg} / \mathrm{kg}$ & $14.56 \pm 0.85^{\mathrm{a} * *}$ & $\begin{array}{l}10.98 \pm 0.66^{\mathrm{a} * *} \\
\mathrm{~b}_{* *}\end{array}$ & $\begin{array}{l}5.68 \pm 0.67^{\mathrm{a} *} \\
\mathrm{~b}_{* *}\end{array}$ & $0.058 \pm 0.09^{\mathrm{a}} *$ & $\begin{array}{l}36.76 \pm 1.53^{\mathrm{a} * *} \\
\mathrm{~b}_{* *}\end{array}$ \\
\hline
\end{tabular}

Value (mean \pm SEM) a=control vs $250 \mathrm{mg} / \mathrm{kg}$ and $500 \mathrm{mg} / \mathrm{kg}, \mathrm{b}=250 \mathrm{mg} / \mathrm{kg}$ vs $500 \mathrm{mg} / \mathrm{kg}, * \mathrm{P}<0.05, * * \mathrm{P}<0.01$, $* * * \mathrm{P}<0.001$.

Table 2: Serum testosterone levels in control and experimental rats.

\begin{tabular}{ll}
\hline Group & Testosterone concentration $(\mathbf{n g} / \mathbf{m l})$ \\
\hline Control & $8.20 \pm 0.91$ \\
$\mathbf{2 5 0} \mathbf{m g} / \mathbf{k g}$ & $5.78 \pm 2.24^{\mathrm{a} * *}$ \\
$\mathbf{5 0 0} \mathbf{m g} / \mathbf{k g}$ & $3.92 \pm 1.01^{\mathrm{a} * * *} \mathrm{~b}_{* * *}$ \\
\hline
\end{tabular}

Value (mean \pm SEM) a =control vs $250 \mathrm{mg} / \mathrm{kg}$ and $500 \mathrm{mg} / \mathrm{kg}, \mathrm{b}=250 \mathrm{mg} / \mathrm{kg}$ vs $500 \mathrm{mg} / \mathrm{kg}, * \mathrm{P}<0.05, * * \mathrm{P}<0.01$, $* * * \mathrm{P}<0.001$.

Table 3: Histometrical analysis of testes of control and male rats treated with extracts for 8 weeks.

\begin{tabular}{|c|c|c|c|c|c|}
\hline Group & $\begin{array}{c}\text { Tunical } \\
\text { thickness } \\
(\mu \mathrm{m})\end{array}$ & $\begin{array}{c}\text { Epithelial } \\
\text { height ( } \mu \mathrm{m})\end{array}$ & $\begin{array}{c}\text { Seminiferous } \\
\text { tubule } \\
\text { diameter } \\
(\mu \mathrm{m})\end{array}$ & $\begin{array}{c}\text { Leydig cell } \\
\text { nuclear } \\
\text { diameter }(\mu \mathrm{m})\end{array}$ & $\begin{array}{c}\text { Sertoli cell } \\
\text { nuclear } \\
\text { diameter }(\mu \mathrm{m})\end{array}$ \\
\hline Control & $20.26 \pm 0.88$ & $52.97 \pm 0.87$ & $176.82 \pm 6.36$ & $9.02 \pm 0.16$ & $9.64 \pm 0.15$ \\
\hline $250 \mathrm{mg} / \mathrm{kg}$ & $16.31 \pm 0.23^{\mathrm{a} *}$ & $\begin{array}{c}34.83 \pm 0.70 \\
\mathrm{a} * * *\end{array}$ & $\underset{\mathrm{a} * *}{162.50 \pm 4.34}$ & $5.80 \pm 0.21^{\mathrm{a}} * *$ & $7.83 \pm 0.29^{\mathrm{a} * *}$ \\
\hline $500 \mathrm{mg} / \mathrm{kg}$ & $\begin{array}{l}12.48 \pm 0.57 \\
a_{* *} b_{* * *}\end{array}$ & $\begin{array}{c}30.50 \pm 1.06 \\
\mathrm{a}_{* * *} \mathrm{~b} * * *\end{array}$ & $\begin{array}{c}144.68 \pm 2.38 \\
\mathrm{a}_{* * *} \mathrm{~b}_{* * *}\end{array}$ & $\frac{4.26 \pm 0.16^{\mathrm{a}} * * *}{\mathrm{~b}_{* * *}}$ & $\begin{array}{c}7.36 \pm 0.24^{\mathrm{a}} * * * \\
\mathrm{~b}_{* * *}\end{array}$ \\
\hline
\end{tabular}

Value (mean \pm SEM) a =control vs $250 \mathrm{mg} / \mathrm{kg}$ and $500 \mathrm{mg} / \mathrm{kg}, \mathrm{b}=250 \mathrm{mg} / \mathrm{kg}$ vs $500 \mathrm{mg} / \mathrm{kg}, * \mathrm{P}<0.05, * * \mathrm{P}<0.01$, $* * * \mathrm{P}<0.001$.

Table 4.Histometrical analysis of epididymis of control and male rats treated with extract for 8 weeks.

\begin{tabular}{|c|c|c|c|c|c|c|}
\hline Group & $\begin{array}{l}\text { Caput } \\
\text { epithelial } \\
\text { height } \\
(\mu \mathrm{m})\end{array}$ & $\begin{array}{l}\text { Caput } \\
\text { tubule } \\
\text { diameter }(\boldsymbol{\mu} \\
\text { m) }\end{array}$ & $\begin{array}{l}\text { Corpus } \\
\text { epithelial } \\
\text { height } \\
(\mu \mathrm{m})\end{array}$ & $\begin{array}{l}\text { Corpus } \\
\text { tubule } \\
\text { diameter }(\boldsymbol{\mu} \\
\text { m) }\end{array}$ & $\begin{array}{l}\text { Cauda } \\
\text { epithelia } \\
\text { l } \\
\text { height }(\mu \\
\text { m) }\end{array}$ & $\begin{array}{l}\text { Cauda } \\
\text { tubule } \\
\text { diameter }(\mu \\
\text { m) }\end{array}$ \\
\hline Control & $\begin{array}{l}28.63 \pm 0.5 \\
0\end{array}$ & $\begin{array}{l}120.06 \pm 2.6 \\
8\end{array}$ & $26.44 \pm 0.95$ & $\begin{array}{l}148.68 \pm 1.5 \\
0\end{array}$ & $\begin{array}{l}20.26 \pm 0 \\
64\end{array}$ & $\begin{array}{l}160.02 \pm 4.6 \\
2\end{array}$ \\
\hline $\begin{array}{l}250 \mathrm{mg} / \mathrm{k} \\
\mathrm{g}\end{array}$ & $\begin{array}{l}28.32 \pm 0.6 \\
2\end{array}$ & $\begin{array}{l}108.66 \pm 1.5 \\
0^{\mathrm{a} *}\end{array}$ & $\begin{array}{l}22.75 \pm 0.32 \\
a_{*}\end{array}$ & $\begin{array}{l}146.80 \pm 4.6 \\
3\end{array}$ & $\begin{array}{l}19.32 \pm 0 . \\
53\end{array}$ & $\begin{array}{l}158.60 \pm 4.2 \\
4\end{array}$ \\
\hline $\begin{array}{l}500 \mathrm{mg} / \mathrm{k} \\
\mathrm{g}\end{array}$ & $\begin{array}{l}26.42 \pm 0.5 \\
4\end{array}$ & $\begin{array}{l}96.20 \pm 0.85 \\
a_{*}\end{array}$ & $\underset{\mathrm{a} *}{20.16 \pm 0.48}$ & $\begin{array}{l}144.50 \pm 2.6 \\
8^{a} *\end{array}$ & $\begin{array}{l}18.26 \pm 0 . \\
68\end{array}$ & $\begin{array}{l}155.71 \pm 3.7 \\
5^{\mathrm{a} *}\end{array}$ \\
\hline
\end{tabular}

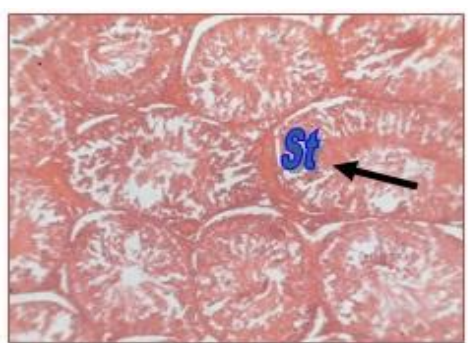

Fig 1: Testis of con showing alteration

ol animal showing well arranged seminiferous tubules

(St) and nomal process of Spermatogenesis. (H \& E X 400).

(St), damaged basement

membrane, loss of interstitial tissue (Is) and

Ley dig cells (L). (H \& E X 400).

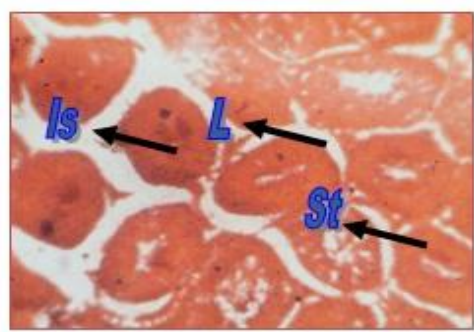

Fig 2: Testis of $250 \mathrm{mg} / \mathrm{kg}$

of seminiferous tubules 


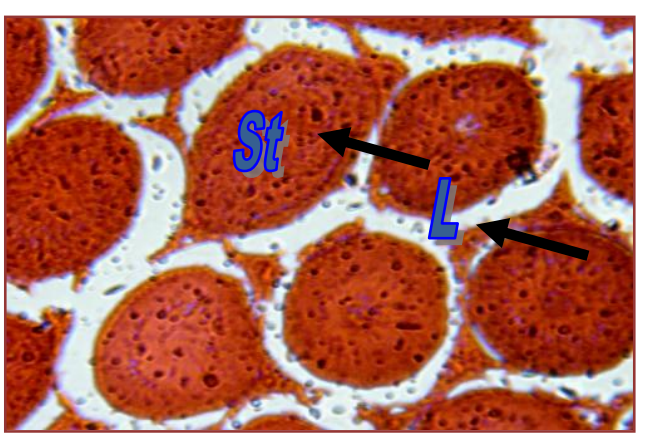

Fig 3: Testis of $500 \mathrm{mg} / \mathrm{kg}$ showing necrotic seminiferous tubules compactly packed (St), shrunken nuclei, total arrest of spermatogenesis and total loss of Leydig cells (L), ( H \& E X 400).

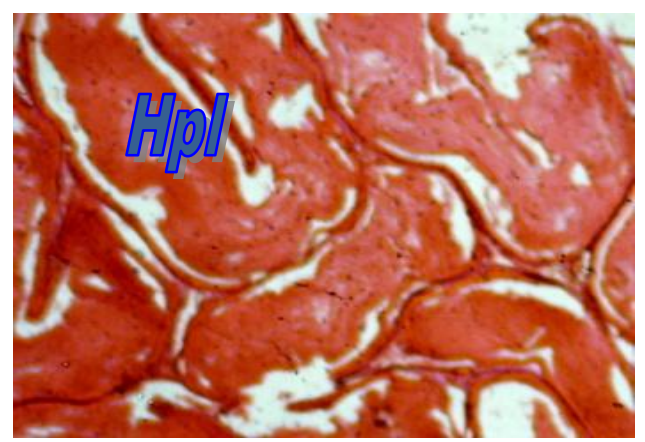

Fig 5: Epididymis of 250mg/kg showing hypertrophy of lumen (Hpl). (H \& E X 400)

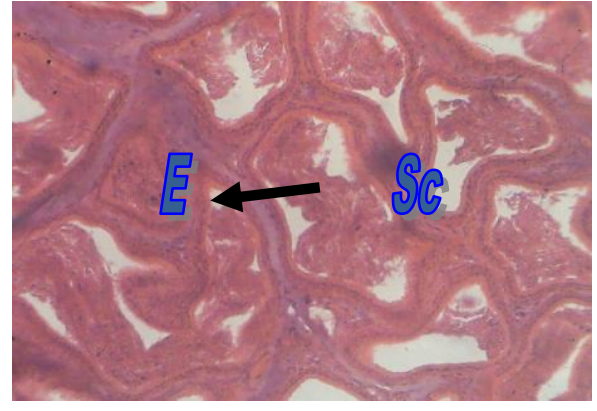

Fig 4: Epididymis of control showing tubules lined with well defined epithelium (E) and filled with sperm cells (Sc). ( H \& E X 400).

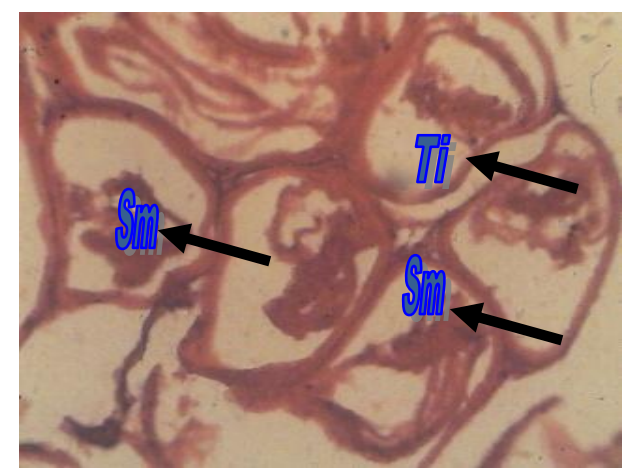

Fig 6: Epididymis of $500 \mathrm{mg} / \mathrm{kg}$ showing thin epithelial lining (Tl)and loss of spermatic elements (Sm). ( H \& E 400).

\section{Discussion}

Medicinal plants play a major role in health care irrespective of advances in modern medicine. These plants are distributed worldwide, although more abundant in tropical regions. Pharmaceutical companies have demonstrated interest in the investigation of higher plants as sources for new lead structures and for development of phytotherapeutic agents with proven efficacy, safety and quality [28-31]. Population explosion is one of the biggest challenges prevalent in third world countries, Nigeria not excluded, having severe consequences on every aspect of development such as employment, sanitation and environment, education, housing and health care. Majority of the population dwell in rural areas without any approach to modern methods of family planning thereby relying on herbal medicines to control population growth rate, such as inducing abortion, prevent conception and sterilization of either the couple. Literature abounds on research carried out on medicinal plants with antifertility effects [32-40]. The findings of the present study showed that ethanolic extract of Spondias mombin significantly altered the fertility potential of male rats. The significant decrease in the organ weights of the treated animals is indicative of the toxic effect of the extract. Decrease in organ weight after administration of a chemical agent has been reported by Simons et al [41] to be an indicator of toxicity. The high significant decrease observed in the weights of testis and epididymis of treated animals at $500 \mathrm{mg} / \mathrm{kg}$ may be due to loss of spermatogenic elements in the testis and the absence of sperm in the epididymis. Several reports have shown degenerative changes in seminiferous tubules without a significant change in organ weight [42]. This contradicts our findings and may be due to the duration of extract administration in this present study.

Alterations of histological features were more pronounced at high dose of $500 \mathrm{mg} / \mathrm{kg}$; disruption in seminiferous tubular arrangement was observed with fewer Leydig cells present. Purohit and Dixit [43] had earlier reported alteration of Leydig cell function in rats treated with aqueous extract of azadirachta indica. Necrotic germ cells were found in the seminiferous tubules of high dose treatment which may indicate that treatment caused severe impediment in the spermatogenetic process.

Significant decrease was recorded in serum testosterone level in the treatment groups especially at high dose compared to control. This may be due to the deleterious effect on Leydig cell that may consequently be responsible for testicular and epididymal dysfunction as a result of androgen deprivation. This may in 
essence affect the process of sperm production and maturation in both organs leading to loss of fertility in treated rats. Similarly, Dixit and Joshi [44] reported the effect of allium sativum on testicular function that led to sterility.

\section{Conclusion}

The present results suggest that administration of ethanolic leaf extract of Spondias mombin at $250 \mathrm{mg} / \mathrm{kg}$ and $500 \mathrm{mg} / \mathrm{kg}$ body weights caused impairment of testicular and epididymal structures, which led to significant decrease in spermatogenic activity in seminiferous tubules. Depletion of Leydig cells in tubular interstitial also caused reduction in serum testosterone level. Therefore, the process of maturation of spermatogenic cells and sperm production in the organs was affected by the extract administration which may lead to infertility in treated rats.

\section{References}

[1.] P. Ziarati, Determination of Contaminants in Some Iranian Popular Herbal Medicines. Journal of Environment and Analytic Toxicology, 2, 2012, 120. DOI: 10.4172/2161- 0525.1000120.

[2.] J.B. Calixto, Efficacy, safety,quality control, marketing and regulatory guidelines for herbal medicines. Brazilian Journal of Medicine and .Biological Research, 33, 2000, 179-189. ISSN : 0100-879X.

[3.] G. Bodeker, C.K. Ong, C. Grundy, G. Burford and K. Shein, WHO Global Atlas of Traditional, Complementary and Alternative Medicine. World Health Organization, Geneva, 2005.

[4.] G. Shweta, R. Chetna, S. Jinkal, N. Shah and J. Hitesh, Herbal plants used as contraceptives. International Journal of Current Pharmaceutical Review and Research. Vol 2, Issue 1, 2011, ISSN 0976-822X.

[5.] F. Ngari, Forests plants used in Ragati, Mt Keny. $1^{\text {st }}$ Edn., VDM Verlag Dr MuellervE.k., Saabrucken, ISBN: 3639215281, pp76, 2010 .

[6.] S. N. Upadhyay, C. Kaushic and G. P. Talwar, Antifertility effects of neem (Azadirachta indica) oil in male rats by single intrauterine administration: a novel method for contraception. Proc. Biol. Sci 242(1305), 1990, 175-9. PMID: 1983033.

[7.] S. N. Upadhyay, S. Dhawan and G. P. Talwar, Antifertility effects of neem (Azadirachta indica) oil in male rats by single intra-vas administration: an alternate approach to vasectomy. Journal of Andrology, 14, 1993,275-281. PMID: 8226307.

[8.] N. Y. C. Noumi and C. Tchakonang, Plants used as abortifacients in the Sangmelima region of Southern Cameroon. Journal of Ethnopharmacology, 76 (3), 2001, 263-268. PMID: 11448548.

[9.] K. Chakrabarti, S. Pal and A. K. Bhattacharyya, Sperm immobilization activity of Allium sativum L and other plant extracts. Asian Journal of Andrology, 5, 2003, 131-135.

[10.] C. Ciganda and A. Laborde, Herbal Infusions used for induced abortion. Journal of Toxicology and.Clinical Toxicology, 41(3), 2003, 235-239. PMID: 12807304.

[11.] M. M. Girini, R. N. Ahamed and R. H. Aldakatti, Effect of graded doses of Mormodica charantia seed extract on rat sperm: scanning electron microscope study. Journal of Basic and Clinical Physiology and Pharmacology, 16(1), 2005, 53-66.

[12.] I. Hammami, A. Nahdi, C. Mauduit, M. Benahmed, m. Amri, A. Ben Amar, S. Zekri, A. ElMay and M. V. ElMay, The inhibitory effects on adult male reproductive functions of crude garlic (Allium sativum) feeding. Asian Journal of Andrology, 10(4), 2008, 593-601.

[13.] V. P.Dixit, V. N. Sharma and N. K. Lohiya, The effect of chronically administered cannabis extract the testicular function of mice. European Journal of Pharmacology, 26, 1974, 111-114. PMID: 4831978.

[14.] G. Z. Liu and K. C. Lyle, Clinical trial of gossypol as a male contraceptive drug. Part II. Hypokalemia study. Fertility and Sterility, 48, 1987, 462-465. PMID: 3305088.

[15.] P. Udoh and A. Kehinde, Studies on antifertility effect of pawpaw seeds (Carica papaya) on the gonads of male albino rats. Phytotherapy Research, 13, 1999, 226-228. PMID: 10353163.

[16.] P. Udoh and J. Ekpenyong, Effect of Mucuna urens (horse eyes bean) on the gonads of male guinea pigs. Phytotherapy Research, 5(2), 2001, 99-102. DOI: 10.1002/ptr.699.

[17.] R. J. Verma and N. J Chinoy, Effect of papaya seed extract on microenvironment of cauda epididymis. Asian Journal of Andrology, 3, 2001, 143-146. ISSN: 1008-682X.

[18.] A. O. Ayoka, R.O. Akomolafe, O.S. Akinsomisoye and O.E. Ukponmwan, Medicinal and economic value of Spondias mombin. African Journal of Biomedical Research, 11, 2008, 129-136. ISSN: 1119-5096.

[19.] P. I. Akubue, G. C. Mittal and C. N. Aguwa, Preliminary pharmacological study of some Nigerian medicinal plants. Journal of Ethnopharmacolgy, 8, 1983, 53 - 63. PMID: 6632937.

[20.] V. N. Offiah and I. I. Anyanwu, Abortifacient activity of an aqueous extract of Spondias mombin leaves. Journal of Ethnopharmacology, 26, 1989, 317-320. PMID: 2615412.

[21.] A. O. Ajao and O. Shonukan, Antibacterial effect of aqueous and alcohol extracts of Spondias mombin and Alchomea cardifolia: two local antimicrobial remedies. International Journal of Crude Drug Research, 23, 1985, 67 - 72. DOI: $10.3109 / 13880208509069004$.

[22.] C. N. Uchendu and T. Isek, Antifertility activity of aqueous ethanolic leaf extract of Spondias mombin (Anacardiaceae) in rats. Journal of African.Health Science, 8(3), 2008, 163-167. PMID: 19357744.

[23.] A. O. Ayoka, R. O. Akomolafe, E. O Iwalewa and O. E. Ukponmwan, Studies on the anxiolytic effect of Spondias mombin L (Anacardiaceae) extracts. African. Journal of Traditional,Complimentary and Alternative Medicine. 2(2), 2005, 153-165. ISSN: 0189-6016.

[24.] A. O. Ayoka, R. O. Akomolafe, E. O. Iwalewa, M. A. Akanma and O. E. Ukponmwan, Sedative, epileptic and antipsychotic effects of Spondias mombin L (Anacardiaceae) in mice and rats. Journal of Ethnopharmacology, 103(2), 2006, 166-175. PMID: 16188408.

[25.] C.S. Nworu, P.A. Akah, F.B. Okoye, D.K. Toukam, J. Udeh and C. O Esimone, The leaf extract of Spondias mombin 1 displays an anti-inflammatory effect and suppresses inducible formation of tumor necrosis factor- $\alpha$ and nitic oxide (NO). Journal of Immunotoxicology, 8(1), 2011, 10-16. PMID: 21261441.

[26.] Y. Raji, M.A. Gbadegesin, O. A. Osonuga, R. A. Adisa, O. S. Akinsomisoye, F.O. Awobajo, O.T. Kunle-Alabi, P.R.C. Esegbue Peters, I.O. Osonuga and A.F. Lamidi, Reproductive, Haematologic and Biochemical profiles of male rats treated with aqueous extract of Spondias mombin bark. International Journal of Pharmacology, 2 (1), 2006, 126 - 130. DOI: 10.3923/ijp.2006.126.130.

[27.] R.O. Adome, J.W. Gachihi, B. Onegi, J. Tamale and S.O. Apio, The Cardiotonic effect of the crude ethanolic extract of Nerium oleander in the isolated guinea pig hearts. African Health Sciences, 3, 2003, 77-82. PMID: 12913798. 
[28.] P. Brevoort, The U.S. botanical market. An overview. HerbalGram, 36, 1995, 49-59.

[29.] P.A.G.M. De Smet, The role of plant derived drugs and herbal medicines in health care. Drugs, 54, 1997, 801-840. PMID: 9421691.

[30.] M. Blumenthal, Harvard study estimates consumers spend $\$ 5.1$ billion on herbal products? HerbalGram, 45, $1996 \mathrm{a}, 68$.

[31.] M. Blumenthal, Herb industry sees mergers, acquisitions, and entry by pharmaceutical giants in 1998. HerbalGram, 45, 1996b, 6768.

[32.] P. M. Zavos and Z. P. N. Zavos, The inhibitory effect of gossypol on human sperm motility characteristics: possible modes of reversibility of those effects. Tohuku Journal of Experimental Medicine, 179, 1996, 167-175.

[33.] J. Bai and Y. Shi,. Inhibition of T-type $\mathrm{Ca}^{2+}$ currents in mouse spermatogenic cells by gossypol, an antifertility compound. European Journal of Pharmacology, 440(1), 2002, 1-6. PMID: 11959082.

[34.] N.K. Lohiya, B. Manivannan, P.K. Mishra, N. Pathak, S. Sriram, S. S Bhande, and S. Panneerdoss, Chloroform extract of Carica papaya seeds induces long term reversible azoospermia on Langur monkey. Asian Journal of Andrology, 4(1), 2002, 17-26.

[35.] S. Parveen, S. Das, C.P. Kundra and B. M. Pereira, A comprehensive evaluation of the reproductive toxicity of Quassia amarain male rats. Reproductive Toxicity, 17(1), 2003, 45-50.

[36.] R.S. Gupta, R. Choudhary, R.K. Yadav, S.K. Verma and M. P. Dobhal, Effect of saponins of Albizia lebbeck (Linn) Benth. Bark on the reproductive system of male albino rats. Journal of Ethnopharmacology, 96(1-2), 2005, 31-36. Doi: 10.1016/j.jep.2004.07.025.

[37.] X..Zhang, F. Han, P. Gao, D. Yu and S. Liu,. Bioassay-guided fractionation of antifertility components of

[38.] castorbean (Ricinus communis L.) seed extracts. Natural Product Research, 21(11), 2007, 982-989. DOI: $10.1080 / 14786410701371462$.

[39.] A. Chauhan, M. Agarwal, S. Kushwaha and A. Mutreja, Antifertility studies of Aegle marmelos Corr.,an Indian medicinal plant on male albino rats. Egyptian Journal of Biology. 10, 2008, 28-35. ISSN: 1110-6859.

[40.] W. Deng, G. Yongwang and S. Dazhao. Antifertility effects of crude ethanol extracts of Tripterygium hypoglaucum (Levl.) Hutch in male Mongolian gerbils (Meriones unguiculatus). Journal of Applied Animal Research. 39(1), 2011, 44-48. DOI: 10/1080/09712119.2011.570048.

[41.] T. Thirumalai, E. David, S.Viviyan Therasa and E. K. Elumalai, Effect of Solanum surattense seed on the oxidative potential of cauda epididymal spermatozoa. Asian Pacific Jourournal of Tropical Biomedicine, 2(1), 2012, 21-23. DOI: 10.1016/S222116919(11)60183-4.

[42.] J.E. Simmons, R.S.H Yang and E. Berman, Evaluation of the nephrotoxicity of complex mixtures containing organics and metals: advantages and disadvantages of the use of real-world complex mixtures. Environmental Health Perspective, 103, 1995 67-71. PMCID: 1519327.

[43.] R. K. Mishra and S. K .Singh, Reversible antifertility effect of aqueous rhizome extract of Curcuma longa L in male laboratory mice. Contraception, 79, 2009, 479-487.

[44.] A. Purohit and V. P. Dixit, Antispermatogenic effectlt of neem (Azadirachta indica A Juss) materials in male rats. Neem Newsletter, $8(2), 1991,13-14$

[45.] V. P Dixit and S Joshi, Effects of chronic administration of garlic (Allium sativum Linn) on testicular function. Journal of Experimental Biology, 20, 1982, 534-536. PMID: 7173985. 